Historic, Archive Document

Do not assume content reflects current scientific knowledge, policies, or practices. 

A99.9

F 763211

Cof 2 USDA Forest Service

Forest Service

Research Paper RM-198

U. S. Department of Agricuiture

December 1977

Rocky Mountain Forest and

Range Experiment Station

Fort Collins, Colorado 80521

\title{
Status of the Gila Topminnow and its Co-occurrence with Mosquitofish
}

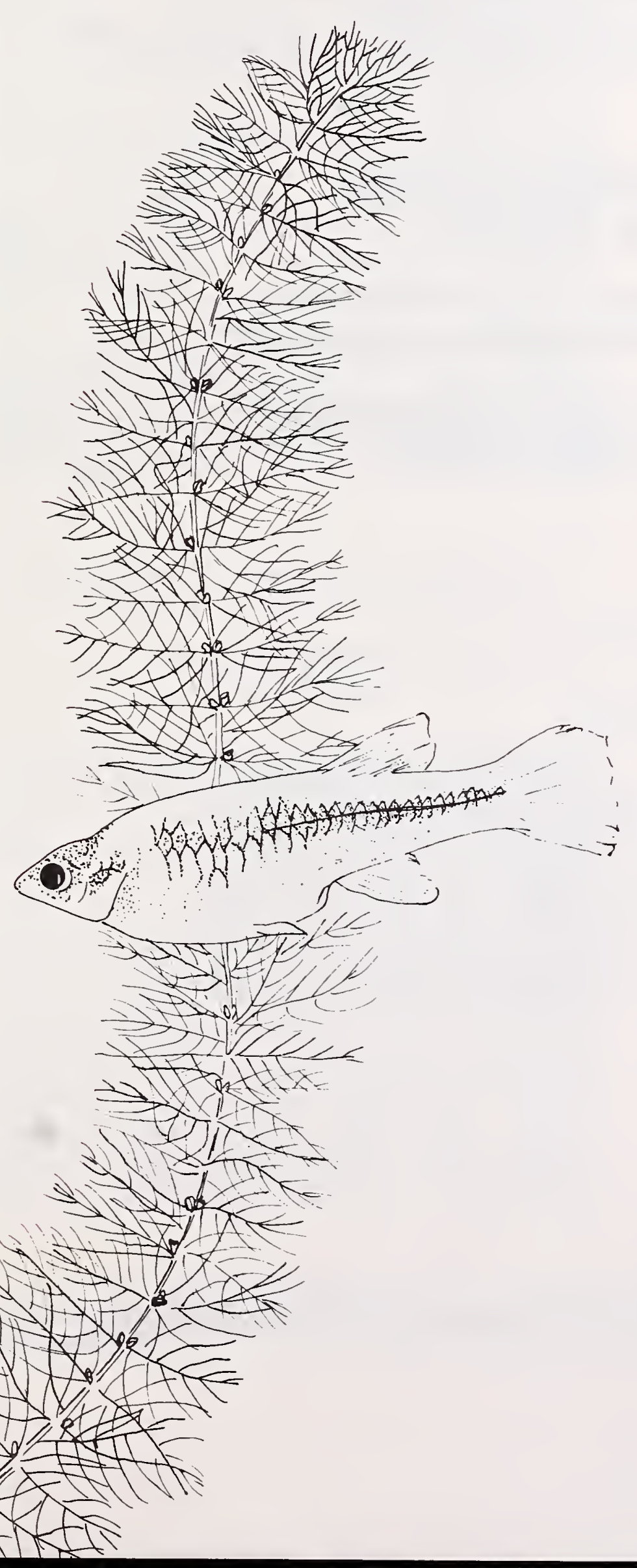

\author{
W. L. Minckley, John N. Rinne, \\ and James E. Johnson
}

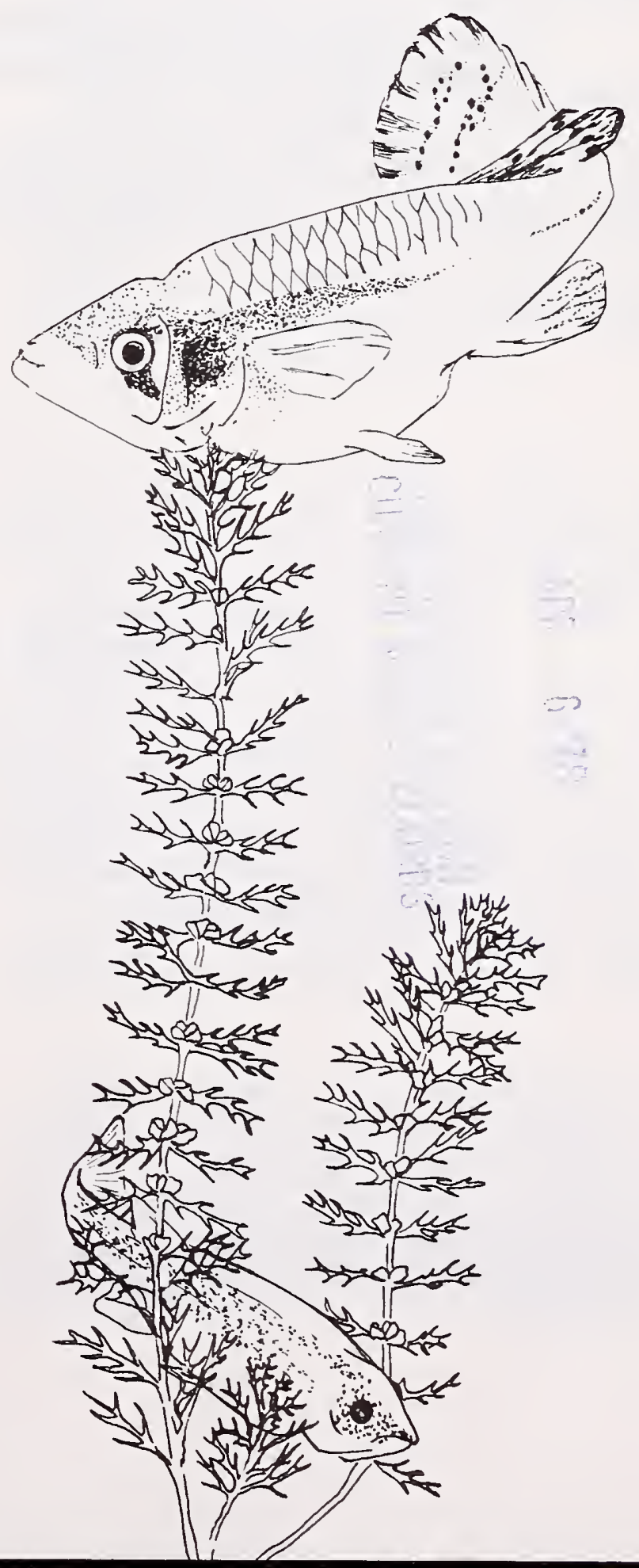




\title{
Status of the Gila Topminnow and its Co-occurrence with Mosquitofish
}

\author{
W. L. Minckley, Professor of Zoology \\ Arizona State University \\ John N. Rinne, Fisheries Research Biologist \\ Rocky Mountain Forest and Range Experiment Station ${ }^{1}$ \\ James E. Johnson, Endangered Species Biologist \\ U. S. Fish and Wildlife Service
}

\begin{abstract}
Discovery of two coexisting populations and examination of museum records indicate that the Gila topminnow (Poeciliidae: Poeciliopsis o. occidentalis) and mosquitofish (Gambusia affinis) occur together for a variable period, especially in complex habitats and adjacent to springs, before the latter ultimately eliminates the former, apparently by direct predation. Surviving populations of Gila topminnow avoid mosquitofish by living in large springs, and, therefore, are available for repopulation if conditions become suitable.
\end{abstract}

\footnotetext{
'Central headquarters is maintained at Fort Collins in cooperation with Colorado State University. Rinne is located at the Station's Research Work Unit at Tempe in cooperation with Arizona State University.
} 


\title{
Status of the Gila Topminnow and its Co-occurrence with Mosquitofish
}

\author{
W. L. Minckley, John N. Rinne, and James E. Johnson
}

\section{Management Highlights}

Gila topminnows were formerly widespread in low-elevation $(<1,800 \mathrm{~m})^{2}$ aquatic habitats throughout much of the arid American Southwest. Constantly flowing springs, marshes (cienegas), and permanent and intermittent streams all provided suitable environments, and prior to 1940 , the species was considered the most abundant "low desert" fish in the area. Reduction and modifications of surface waters, and introductions of non-native species of fishes eliminated most populations; the Gila topminnow is now listed as endangered by the U.S. Department of Interior.

The species prefers relatively shallow $(<20 \mathrm{~cm})$ warm water (generally $>20^{\circ} \mathrm{C}$ ). Under former conditions, such places were used almost exclusively by the topminnow, pupfishes, and seasonally by young of native minnows and

${ }^{2}$ Data in this paper are presented in SI (metric) units. suckers, none of which are highly predaceous on other fish. Introduced fishes, especially mosquitofish and juveniles of sunfish and largemouth bass, prey heavily on adults and young of Gila topminnow, ultimately eliminating the species.

Before the Gila topminnow can be restored to nonendangered status, self-perpetuation of the species must be assured. Achievement of this goal will involve: (1) discovery of natural habitats in which populations may be established; (2) renovation of formerly occupied waters and re-introduction of the species; and (3) creation of quasi-natural habitats in which Gila topminnows may be maintained.

Because of the rapidity with which Gila topminnows are replaced by non-native fishes, in less than a season is some instances, continuous surveillance will be mandatory. Educational programs will help to minimize movement of fishes by unauthorized persons, but enforcement of existing laws and possibly new legislation will be necessary.

\section{Introduction}

The Gila topminnow ${ }^{3}$ is a small poeciliid fish formerly distributed throughout much of the Gila River system of Arizona, New Mexico, and Sonora, Mexico (Hubbs and Miller 1941). It now is greatly reduced in range and abundance (Miller and Lowe 1964, Minckley 1973), and is listed as endangered by the U.S. Department of Interior (1976). This decline has been largely attributed to drastic changes in aquatic habitats in the past 70-80 years (Hastings 1959, Hastings and Turner 1966), and, since about 1930, to predation by non-native, introduced fishes, principally mosquitofish (Miller 1961, Miller and Lowe 1964, Minckley and Deacon 1968, Minckley 1969a, 1973, Schoenherr 1974, 1977).

${ }^{3}$ Scientific names of plants and animals montioned are listed in the Appendices.
Mosquitofish have been demonstrated to eliminate the native livebearer within a year of introduction, both in natural and experimental situations (Minckley and Deacon 1968, Schoenherr 1974).

Routine surveillance of remnant populations of Gila topminnow and resurvey of certain former habitats of the species recently discovered its co-occurrence with mosquitofish. These observations, re-examination of museum and literature records, and sampling by us and personnel of Arizona Game and Fish Department constitute the basis for this report. ${ }^{4}$

\footnotetext{
-Robert R. Miller, University of Michigan Museum of Zoology, provided facilities and assistance in compiling collection records used herein. Arizona Game and Fish Department personnel, James DeVos, Gerald Ginnelly, and William Silvey, assisted in the field, provided original data, and electrofishing equipment. Personnel and students of Fisheries Management classes from Arizona State University were able field assistants.
} 


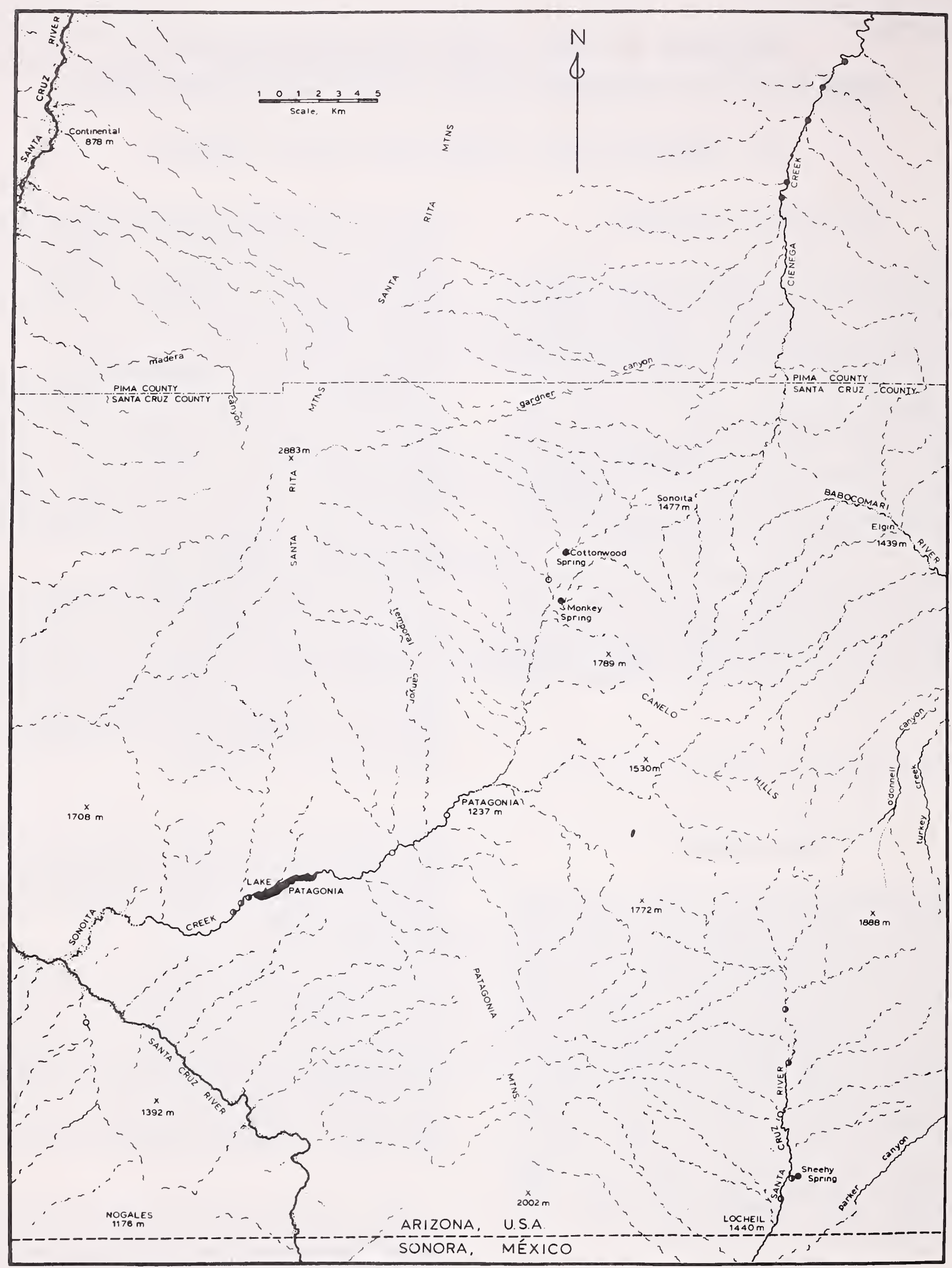

Figure 1. Extant populations (solld circies) of Glla topminnow in the Santa Cruz River headwaters and Sonolta and Clenega Creeks drainages, Pima and Santa Cruz Countles, Arizona. Half-shaded circles denote co-occurence with mosquitofish (1976-77), and open clrcies literature or museum records for the topminnow. 


\section{Study Area}

Collections and observations were made in a number of streams that drain semi-desert oak. grassland in Pima and Santa Cruz Counties, Arizona (fig. 1). Localities in this limited area constitute what is essentially the entire present range of the Gila topminnow with only two additional natural populations known to persist in Bylas Springs and Cocio Wash, Ariz. (Johnson and Kobetich 1970, Constanz 1976).

\section{Methods}

Sampling was accomplished with seines (2 to $5 \mathrm{~m}$ long, 5 to $12 \mathrm{~mm}$ meshes), scape nets, and direct current, electrofishing equipment. Total numbers of each species were recorded by locality, habitat, and gear type in the field. Most native fishes were returned alive to the various habitats, with voucher specimens preserved in $10 \%$ formalin, then transferred to alcohol and housed at Arizona State University. Collections were made under U.S. Fish and Wildlife Service permit numbers PRT2-340 and PRT8-328-C, in conjunction with permits from Arizona Game and Fish Department.

\section{Results}

Gila topminnows were first observed to co-occur with mosquitofish and green sunfish in April 1976 in the Santa Cruz River, a few kilometers northeast of Locheil (fig. 1). That locality (and two others in the immediate vicinity) had been sampled five times in the period 1964-74, without recording Gila topminnow. All available collections at Arizona State University from those years were re-examined for possible errors in sorting of poeciliids, but no topminnows were found. The original fauna of the uppermost Santa Cruz River basin, as determined by examination of early collections housed at the University of Michigan Museum of Zoology, consisted of Gila topminnow, Gila chub, and longfin dace. Gila mountain-sucker and Gila coarse-scaled sucker have been taken infrequently in the basin since 1964. Introduced species known from the area include yellow and black bullhead catfishes, Iargemouth bass, bluegill and green sunfish plus mosquitofish (Minckley 1973).

The uppermost Santa Cruz River (drainage area $213 \mathrm{~km}^{2}$ ) originates in the Canelo Hills at an elevation of about $1,800 \mathrm{~m}$ above mean sea level and flows directly south into México (fig. 1 ). Since 1949 , discharge at a gage $2.8 \mathrm{~km}$ north of the U.S.-Mexican border has ranged from none to almost $140 \mathrm{~m}^{3} /$ second, with a mean near $0.1 \mathrm{~m}^{3} /$ second (U. S. Geological Survey 1975). The stream meanders in a variably incised ( 2 to $6 \mathrm{~m}$ deep) channel cut into silt-sand and organic deposits, and is generally open, with a sparse representation of large riparian trees, prin. cipally cottonwood and willow. Organic deposits are remnants of extensive marsh (cienega) habitats, some of which persist in wider parts of the channel and along spring seepages near terraces. Aquatic vegetation is abundant after periods of low discharge, consisting of sago pondweed, water milfoil, naiad, stonewart, local stands of watercress, and diverse sedges and grasses. Near the headwaters, streambeds are of sand and gravel, but a few kilometers downstream, deep, organic mud and sand are prevalent.

In April 1976, quantitative data were limited to visual estimates of fishes present. About 100 $\mathrm{m}$ of stream was carefully examined at site $\mathrm{A}$ in figure 2, and mosquitofish outnumbered Gila

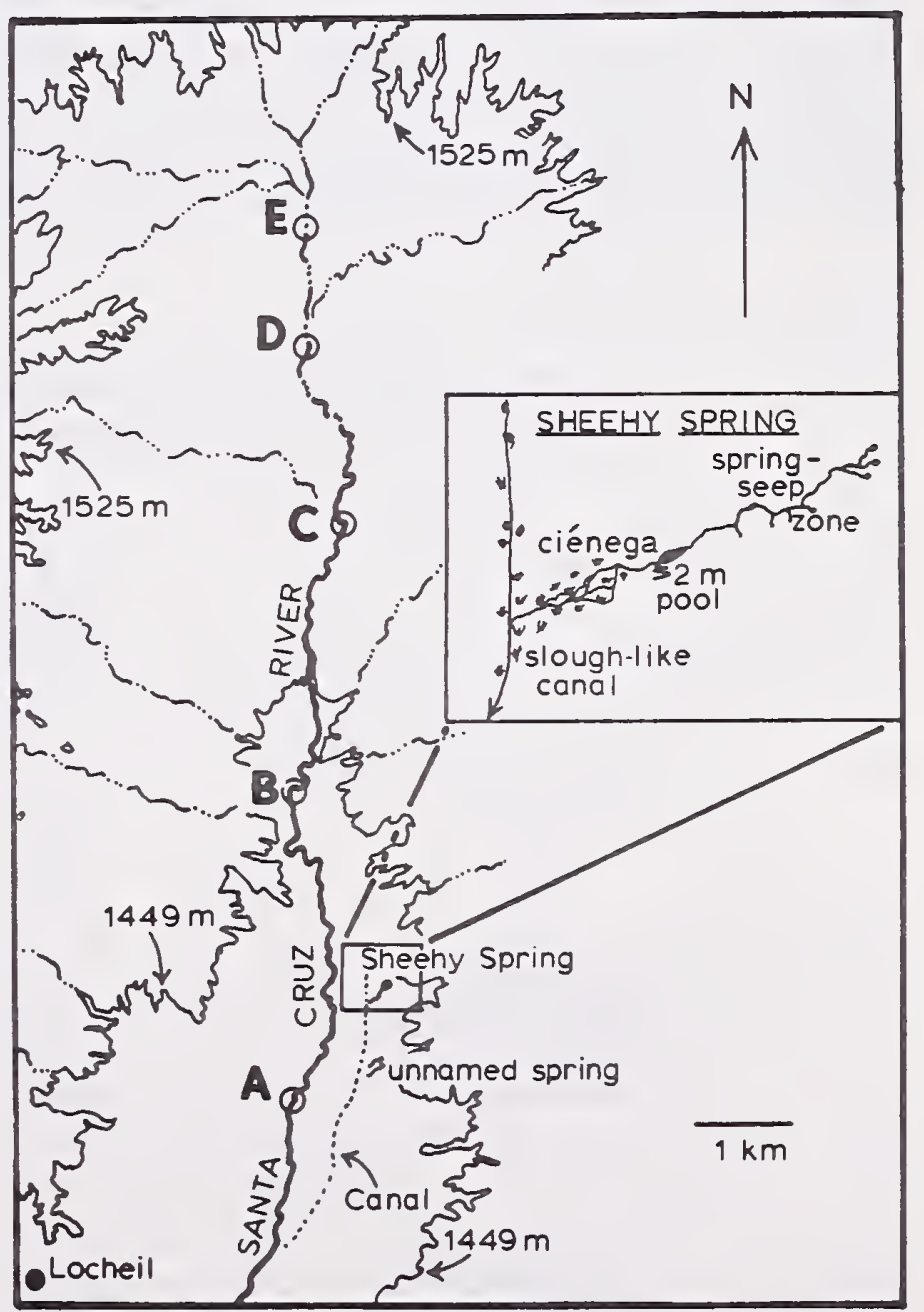

Flgure 2. Upper Santa Cruz RIver basin, Santa Cruz County, Arlzona, showing recent (1976-77) sampling stations. 
topminnow by about 100 to 1 . The disparity was likely even greater than indicated, since shoals of large, female mosquitofish were abundant in quiet water along the channel and in beds of aquatic plants, where numbers would be easily underestimated. However, many Gila topminnows that were observed were darkened, territorial males (Constanz 1974, 1976), allowing some bias toward that species. Streamflow was about $0.01 \mathrm{~m}^{3} /$ second, and long reaches of dry channel separated pools and segments of flow. Two additional localities, north of the site just discussed ( $\mathrm{B}$ and $\mathrm{C}$ in fig. 2) also were examined, but Gila topminnow was not observed; green sunfish and mosquitofish were abundant. The only other native fish seen in April 1976 was longfin dace, which was uncommon in flowing reaches.

In September 1976, flow was continuous throughout much of the upper Santa Cruz River $\left(0.04 \mathrm{~m}^{3} /\right.$ second at the gage, A in fig. 2$)$. Gila topminnows were present in all but a drying pool at the uppermost end of the reach examined ( $E$ in fig. 2), and at an obviously greater abundance than before (estimated at 6 individuals per 150 mosquitofish). All life-history stages of topminnow were present. In no instance were Gila topminnow and mosquitofish adults noted schooling together. There was an obvious tendency for the native poeciliid to be more in open water, and in areas of current. The only other fishes seen were green sunfish and longfin dace, the former extremely abundant and the latter in small numbers.

Gila topminnows were present at collection sites A and D on the mainstream Santa Cruz River in March 1977 (fig. 2, table 1), being greatly outnumbered by mosquitofish at the former (23:1), but less so at the latter (3:1). The native poeciliid was not caught at two intermediate stations (B and C in fig. 2). Green sunfish was rare upstream (D), equally abundant at two stations $\mathrm{A}$ and $\mathrm{C}$, and comprised $97 \%$ of all fishes taken in an isolated pool at locality B.

A sample from an overgrown, slough-like drainage canal on the east side of the Santa Cruz floodplain (fig. 2) contained only a few mosquitofish and green sunfish. A small, unnamed spring about $1 \mathrm{~km}$ upstream from the canal locality, and a few meters above the level floodplain, contained only mosquitofish. Meager flow from that spring passed through a shallow marsh to enter the drainage canal.

Sheehy Spring, upstream from the last locality and also flowing into the canal (fig. 2), contained both the poeciliids and Gila chubs. The spring run was interrupted about midway in its length by a large, natural pool, too deep $(>2.0 \mathrm{~m})$ to sample effectively with available gear. Upstream from that pool, only native

Table 1. Quantitative distributions of sympatric populations of Gila topminnows and mosquitofish and associated fishes, in two streams in southeastern Arizona; March 1977.

\begin{tabular}{|c|c|c|c|c|c|c|}
\hline & 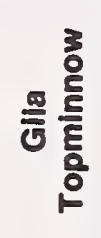 & 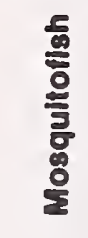 & 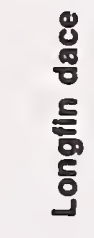 & $\begin{array}{l}\frac{5}{6} \\
\frac{6}{5} \\
\frac{5}{3}\end{array}$ & $\begin{array}{l}\frac{0}{3} \\
\frac{e}{0} \\
\text { 일 }\end{array}$ & 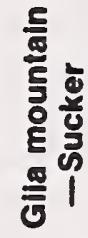 \\
\hline (see figs. 1-2) & \multicolumn{6}{|c|}{ Santa Cruz River } \\
\hline $\bar{A}$ & 10 & 32 & 744 & 100 & 0 & 0 \\
\hline B & 0 & 20 & 0 & 600 & 0 & 12 \\
\hline C & 0 & 17 & 0 & 100 & 0 & 0 \\
\hline D & 6 & 136 & 0 & 2 & 0 & 0 \\
\hline Slough-canal & 0 & 24 & 0 & 15 & 0 & 0 \\
\hline Unnamed spring & 0 & 99 & 0 & 0 & 0 & 0 \\
\hline \multicolumn{7}{|l|}{ Sheehy Sping } \\
\hline Above pool & 129 & 0 & 0 & 0 & 82 & 0 \\
\hline \multirow[t]{2}{*}{ Below pool } & 1 & 265 & 0 & 0 & 22 & 0 \\
\hline & \multicolumn{6}{|c|}{ Sonoita Creek } \\
\hline Borrow pits below & & & & & & \\
\hline Lake Patagonia & 23 & 43 & 0 & 0 & 0 & 0 \\
\hline One km downstream & 1 & 2 & 95 & 0 & 0 & 0 \\
\hline Three km downstream & 23 & 7 & 162 & 0 & 0 & 7 \\
\hline
\end{tabular}


fishes (chubs and topminnow) were present, while downstream, mosquitofish and far fewer Gila chubs were caught (table 1). Electrofishing in the pool yielded two chubs, and no other fishes were seen.

Sonoita Creek also is an incised stream, flowing south then west between the Santa Rita Mountains, and the Canelo Hills (fig. 1). Discharges at a gage $7.6 \mathrm{~km}$ southwest of Patagonia (drainage area ca. $541 \mathrm{~km}^{2}$ ) average about $0.2 \mathrm{~m}^{3} /$ second and range from none to near $400 \mathrm{~m}^{3} /$ second (U.S. Geological Survey 1975). The creek is erosive, with a high percentage of shifting sand bottom and little aquatic vegetation except for local and seasonally abundant watercress. Much of the channel is lined by extensive galleries of cottonwood (Minckley 1969b). Since 1964, Gila topminnow has occurred sporadically in collections from the stream, occupying quiet places behind sand bars formed by flooding from typically dry washes, cut-off pools, and other protected areas. The population was sparse, and presumably replenished upon flooding from Cottonwood and Monkey Springs, a few kilometers upstream (fig. 1).

Early collections from the Sonoita Creek system indicated Gila topminnow were abundant throughout most of the drainage (fig. 1). The fauna consisted of the same five fishes as recorded from the upper Santa Cruz River mainstream, plus speckled dace and a pupfish. Of these, three have been eradicated (Gila chub, Gila coarse-scaled sucker, and pupfish), and at least 12 introduced species have been recorded (goidfish, carp, channel catfish, Yaqui catfish, bleck and yellow bullheads, mosquitofish, green sunfish, bluegill, largemouth bass, and a number of salmonids).

Mosquitofish was rare to absent in the drainage until about 1969 (Minckley 1969b), after which it spread rapidly. Lake Patagonia (fig. 1), filled in the early 1970's, generally stabilized flow in the lowermost part of the creek and provided habitat for a number of introduced fishes adapted to living in still waters. Sonoita Creek formerly percolated into sand of its channel during dry periods, long before entering the Santa Cruz River.

Three extensive collections from the vicinity of the present Lake Patagonia (in 1964, 1967, and 1968) included abundant longfin dace, a few Gila mountain-suckers, and uncommon speckled dace. In December 1972, personnel of
Arizona Game and Fish Department collected many mosquitofish from the lake proper, along with bluegill, largemouth bass, longfin dace, and introduced salmonids. Introduced fishes dominated collections made in 1973-75. However, in December 1976, mosquitofish and Gila topminnow were taken together downstream from the impoundment. In 1977 , our collections from borrow pits near the dam included a few Gila topminnows along with abundant mosquitofish. Downstream, in the creek channel, Gila topminnow comprised more than half the poeciliid fauna, longfin dace dominated the over-all fauna, and Gila mountain-sucker was rare (table 1). As in the Santa Cruz River mainstream, mosquitofish in Sonoita Creek tended to segregate from topminnows into more quiet water, with the topminnow inhabiting places of moderate current along shore or associated with logs and other debris in the channel.

\section{Discussion}

Records of co-occurrence of Gila topminnow and mosquitofish in Arizona date from 1926, when both were collected from the Gila River at Dome, and the Salt River near Tempe, and in 1941 from Tonto Creek upstream from Roosevelt Dam. Gila topminnow was not again taken from the first two places, which are now dry or maintained by wastewater flow (Brown et al. 1977). The native species persisted in Tonto Creek at least until 1951, but only mosquitofish has been taken there since 1964. In 1943, a series of samples from the Gila River system (housed at the University of Michigan) included 11 localities for Gila topminnow, five of which also yielded mosquitofish. Between 1950 and May 1977, resurvey of all known localities for Gila topminnow revealed replacement of the native fish by mosquitofish at 15 , elimination of all aquatic life through desiccation at 7 , and persistence of the native topminnow at 7 isolated springs or segments of stream, including localities of co-occurrence discussed here. In more than 150 samples from the Gila River system below an elevation of $1,800 \mathrm{~m}$ in the period 1964-77, 3 of the 7 present localities for the native poeciliid were discovered as new (Johnson and Kobetich 1970, Constanz 1976), and about 107 collection sites for mosquitofish were recorded (fig. 3a). Not included in the above compilation are records of largely unsuccessful reintroduction sites for Gila topminnow within its natural range (Minckley 1969c, 1973). 

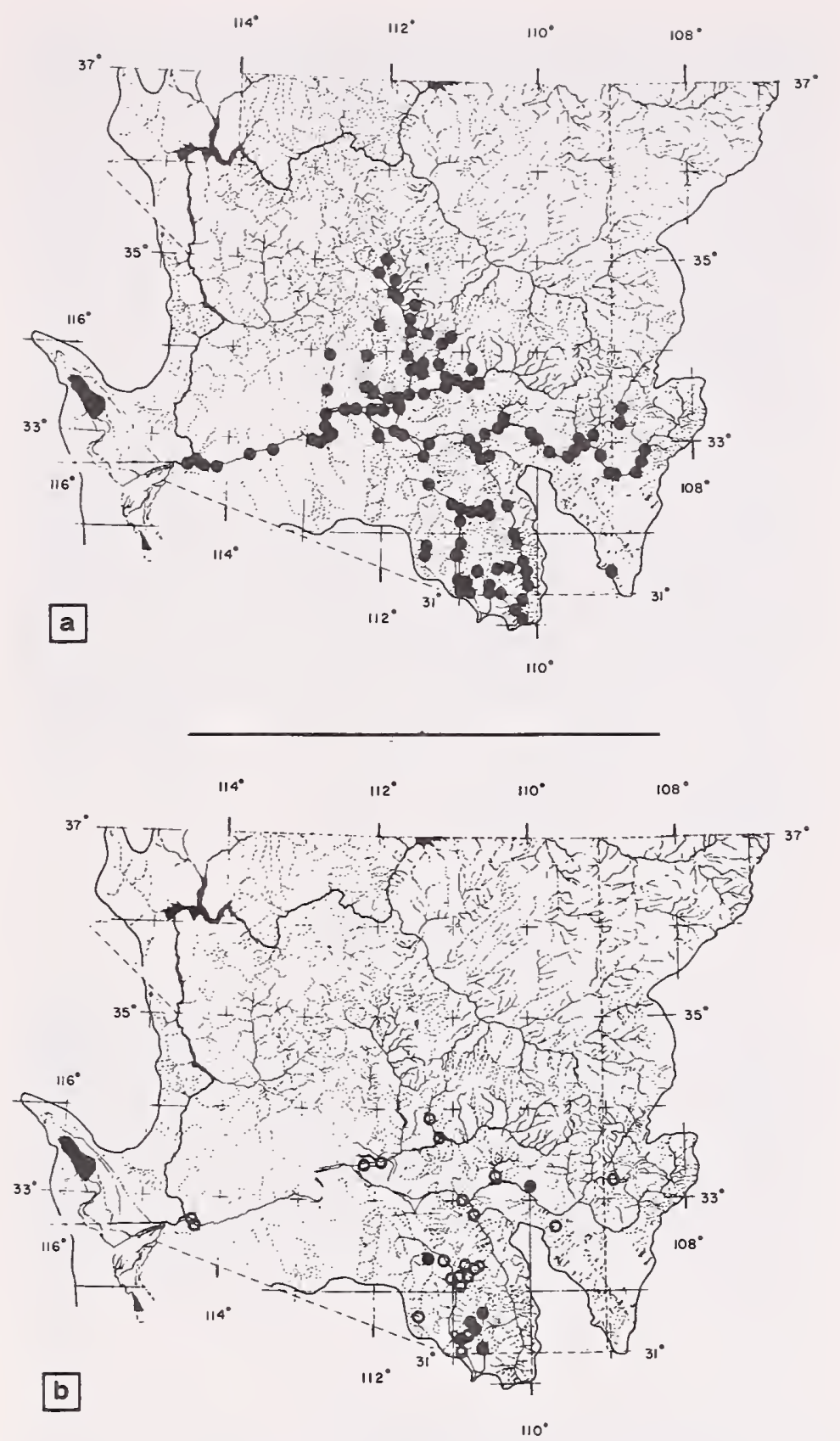

Figure 3. Distribution of mosquitofish (a - besed upon collections housed at Arizona State University) and Glla topminnow ( $b$ - exciuding transplant sltes) in the Glla River basin. Localltles for Glla topminnow are based upon specimens examined by us; dots represent extant populations and open circles denote localltles of former occurrence. The present map supersedes and corrects those published by Minckley (1968a, 1973).

Co-occurrence of the two poeciliids in the upper Santa Cruz River, recorded after a 12-year period of sampling that indicated only the presence of mosquitofish, underscores the difficulties of determining extinction of populations. When mosquitofish were taken in the mainstream, consistently and in large numbers, elimination of Gila topminnow was assumed, and headsprings (e.g. Sheehy Spring) were simply not visited by us until spring 1977.
Also, a substantial portion (about $900 \mathrm{~km}^{2}$ ) of the upper Santa Cruz River drainage is in México, between its exit and re-entry to the United States (fig. 1), and essentially nothing is known of the status of native fishes in that region.

Of native Arizona fishes, only Gila topminnow, chubs of the genus Gila, and occasionally speckled dace, penetrate into immediate outflows of springs. Mosquitofish, on the other hand, rarely occupies springhead habitats within its introduced range in Arizona; in parts of its native range, especially Texas and northern Mexico, headspring habitats are occupied by other species of Gambusia, with mosquitofish living downstream (Hubbs and Springer 1957, Hubbs 1957, and following works). Presumably, headspring populations of Gila topminnow in Arizona have a selective advantage in the constancy of the spring. In the Sonoita Creek drainage, mosquitofish had access to Cottonwood Spring by direct water connection for at least 2 years (Minckley 1969b), but did not penetrate the immediate source populated by Gila topminnows. In Sheehy Spring, source habitat was occupied only by the native poeciliid and Gila chub; mosquitofish and chub, and very rare topminnow lived downstream. Mosquitofish have, however, presumably displaced Gila topminnow from a smaller spring near Sheehy Spring (table 1). Current populations of Gila topminnow, with the exception of Cocio Wash, all occur in or adjacent to constant temperature, permanent springs, or live in drainages where relatively large springs are present. Thus, reservoirs of the native poeciliid are maintained and are locally available to move into adjacent habitats if conditions become suitable.

This rationale may not, however, be used to explain historical co-occurrences of Gila topminnow and mosquitofish. No large springs are known to have existed in or near the lowermost Gila or Salt Rivers, or, more importantly, along the portion of Tonto Creek where the two fishes must have coexisted from 1941 until at least 1951. In the series of collections made in 1943, Gila topminnow was caught in three artificial habitats (ponds or irrigation canals), four habitats identified as or adjacent to springs, and four streams (Gila and San Pedro Rivers, Sabino and Potrero Creeks). Co-occurrences with mosquitofish were in man-made ponds (2) and larger streams (the first three listed; Gila topminnow persisted in Potrero Creek near 
Nogales until 1965, when the habitat dried). Perhaps the pond populations were derived from the Santa Cruz River, near which they were constructed. The larger stream habitats must have been complex enough in their 1943 condition to provide space and diversity within which the two fishes could segregate, so that the topminnow could persist for a time, as we observed in Sonoita Creek and the Santa Cruz River.

\section{Summary and Conclusions}

Published accounts indicate replacement of Gila topminnow by mosquitofish within a brief period after introduction of the latter, usually within a year (Miller 1961, Minckley and Deacon 1968, Minckley 1969a, 1973, Schoenherr 1974). Under experimental conditions, a similar period of co-occurrence is apparent, until the topminnow disappears (Schoenherr 1974). Examination of museum records, however, and discovery of coexisting populations of the two poeciliids, indicate that Gila topminnow and mosquitofish have occurred together for extended periods, especially in complex habitats and adjacent to springs. However, the exotic ultimately replaces the native species, apparently by direct predation (Schoenherr 1974), which also has been reported in instances where mosquitofish suppressed or eliminated other kinds of fishes (Myers 1965).

In the two areas of coexistence, one a modified reach of stream downflow from a recently constructed dam, the other a natural segment of stream, estimates of time of interaction are available. In Sonoita Creek, potential interaction has occurred for 7 years based upon known time of introduction and spread of mosquitofish in the system. The other stream has been populated by mosquitofish for at least 13 years, and topminnow was thought to have been eliminated until rediscovered in 1976.

In both systems, local populations of Gila topminnow live in large springs not inhabited by mosquitofish, and, therefore, are available as a source for repopulation if conditions become suitable. Such a pattern of survival in springheads is consistent with data gleaned from earlier collections and museum records of co-occurrence of the two fishes. Coexisting populations of Gila topminnow and mos. quitofish provide an opportunity to evaluate interactions of the two fishes to determine ways in which the native species may be maintained.

\section{Literature Cited}

Brown, D.E., N.B. Carmony, and R.M. Turner. 1977. Drainage map of Arizona showing perennial streams and some important wetlands. Ariz. Game and Fish Dep., Phoenix.

Constanz, G.D. 1974. Reproductive effort in Poeciliopsis occidentalis (Poeciliidae). Southwest. Nat. 19:47-52.

Constanz, G.D. 1976. Life history strategy of the Gila topminnow, Poeciliopsis occidentalis: a field evaluation of theory on the evolution of life history. Unpubl. Ph.D. Diss., Ariz. State Univ., Tempe.

Hastings, J.R. 1959. Vegetation change and arroyo cutting in southeastern Arizona. J. Ariz. Acad. Sci. 1:60-67.

Hastings, J.R., and R.M. Turner. 1966. The Changing Mile. Univ. of Ariz. Press, Tucson.

Hubbs, C.L., and R.R. Miller. 1941. Studies of the fishes of the order Cyprinodontes. XVII. Genera and species of the Colorado River system. Occ. Pap. Mus. Zool. Univ. Mich. 433:1-9.

Hubbs, C. 1957. Gambusia heterochir, a new poeciliid fish from Texas, with an account of its hybridization with G. affinis. Tulane Stud. Zool. 5:1-16.

Hubbs, C. 1959. Population analysis of a hybrid swarm between Gambusia affinis and G. heterochir. Evolution 13:236-246.

Hubbs, C. 1971. Competition and isolation mechanisms in the Gambusia affinis X $G$. heterochir hybrid swarm. Bull. Tex. Mem. Mus. 19:1-47.

Hubbs, C., and V.G. Springer. 1957. A revision of the Gambusia nobilis species group, with descriptions of three new species, and notes on their variation, ecology and evolution. Tex. J. Sci. 9:279-327.

Johnson, J.E., and G. Kobetich. 1970. A new locality for the Gila topminnow, Poeciliopsis occidentalis (Poeciliidae). Southwest. Nat. 14:368.

Miller, R.R. 1961. Man and the changing fish fauna of the American Southwest. Pap. Mich. Acad. Sci.,Arts, Lett. 46:365-404.

Miller, R.R., and C.H. Lowe. 1964. Part 2. An annotated checklist of the fishes of Arizona. In, The vertebrates of Arizona, C.H. Lowe, ed. Univ. of Ariz. Press, Tucson. p. 133-155. 
Minckley, W.L. 1969a. Native Arizona fishes, Part 1 - Livebearers. Wildl. Views 16:6-8.

Minckley, W.L. 1969b. Aquatic biota of the Sonoita Creek basin, Santa Cruz County, Arizona. Ecol. Stud. Leafl. 15:1-8.

Minckley, W.L. 1969c. Attempted re-establishment of the Gila topminnow within its former range. Copeia 1969:193-194.

Minckley, W.L. 1973. Fishes of Arizona. Ariz. Game and Fish Dep., Phoenix.

Minckley, W.L., and J.E. Deacon. 1968. Southwestern fishes and the enigma of "endangered species". Science 159:1424-1432.

Myers, G.S. 1965. The fish destroyer. Trop. Fish Hobbyist 1965:31-35.
Schoenherr, A. 1974. Life history of Gila topminnow Poeciliopsis occidentalis (Baird and Girard) in Arizona and an analysis of its interaction with mosquitofish Gambusia affinis (Baird and Girard). Unpubl. Ph.D. Diss., Ariz. State Univ., Tempe.

Schoenherr, A. 1977. Density dependent and density independent regulation of reproduction in the Gila topminnow, Poeciliopsis occidentalis (Baird and Girard). Ecology 58:438-444.

U.S. Department of the Interior. 1976. Endangered and threatened wildlife and plants. [republication of list of species] Fed. Reg. 41(208):47180-47198.

U.S. Geological Survey. 1975. Surface water supply of the United States, 1966-70. Part 9. Colorado River basin. Volume 3. Lower Colorado River basin. U.S. Geol. Surv. WaterSuppl. Pap. 2126:i-viii, 1-681.

\section{Appendix}

Common and scientific names of fishes

longfin dace

goldfish

carp

speckled dace

Gila coarse-scaled sucker

Gila mountain-sucker

black bullhead

yellow bullhead

Yaqui catfish channel catfish

mosquitofish

Gila topminnow

Monkey spring pupfish green sunfish

bluegill sunfish

largemouth bass
Agosia chrysogaster

Carassius auratus

Cyprinus carpio

Rhinichthys o. osculus

Catostomus insignis

Pantosteus clarki

Ictalurus melas

Ictalurus natalis

Ictalurus pricei

Ictalurus punctatus

Gambusia affinis

Poeciliopsis 0. occidentalis

Cyprinodon sp.

Chaenobryttus cyanellus

Lepomis macrochirus

Micropterus

salmoides
Common and scientific names of plants

Trees

oak

cottonwood

willow

Quercus spp.

Populus fremontii

Salix spp.

\section{Aquatic plants}

sago pondweed water milfoil

naiad

stonewart

watercress

\author{
Potamogeton pectinatus \\ Myriophyllum spp. \\ Najas guadalupensis \\ Chara spp. \\ Rorripa nasturtium- \\ aquaticum
}




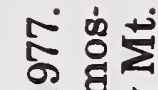

동 젱

용

¿

렁 $\infty$ 용

미 익 $\infty$

\% 융

实

๙ิ 8 مि

on.

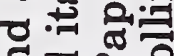

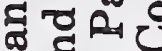

๑

3 क्ष

. 일

도 녕

Z 욯

로응 웅 욱

○

- न्न 4

¿ण口

๑

吉国

넝 동으

خे

숭 웅

扱宗医

$\sum$

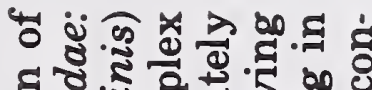

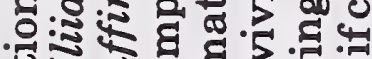

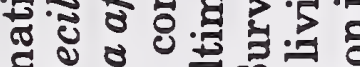

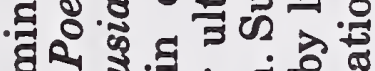

ซึ 0.

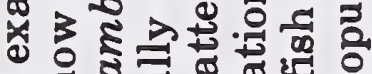

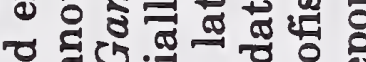

도잉

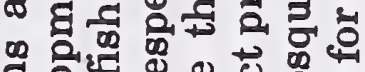

द्ञ

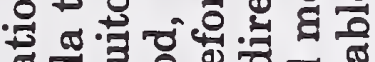

क

30 品

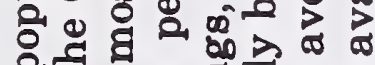

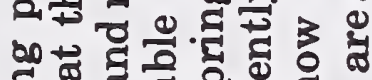

동 क

品

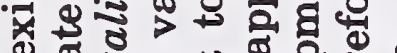

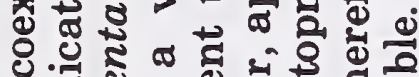

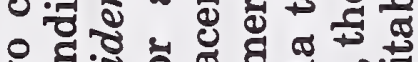

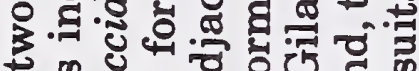

๘

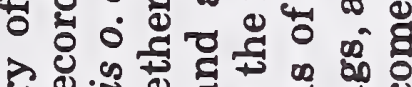

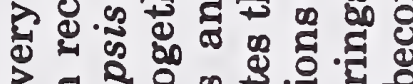

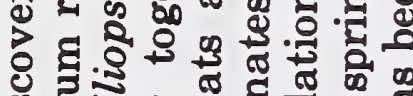

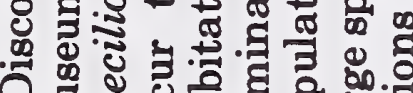

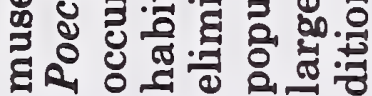

8

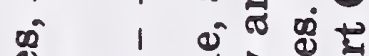

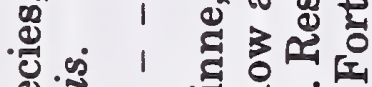

ఖ 1 :

कृ ।

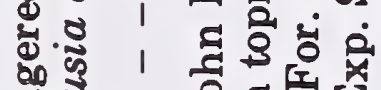

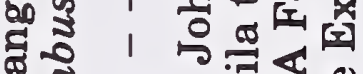

है

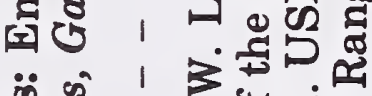

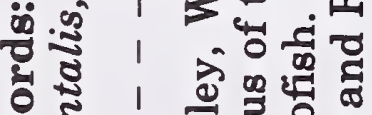

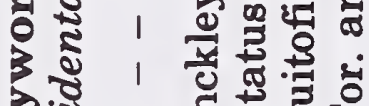

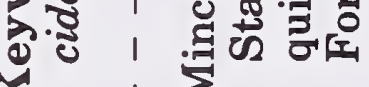

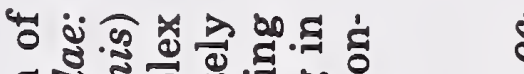

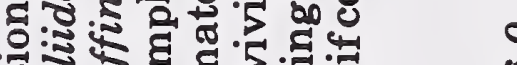

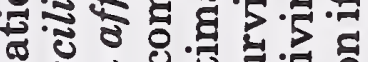

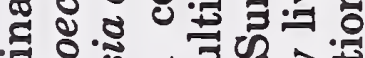

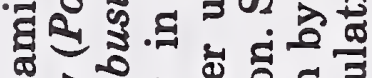

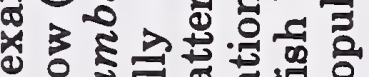

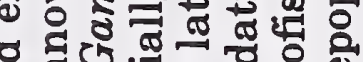

.

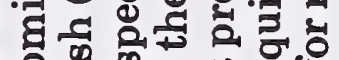

$\infty$ 电嵒

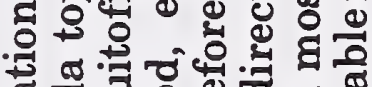

矛

ช 웡

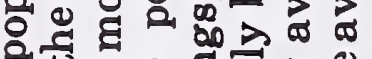

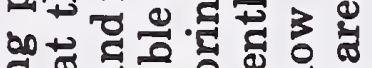

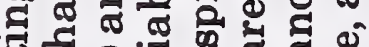

.

붕

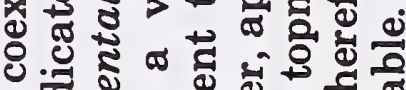

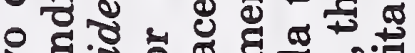

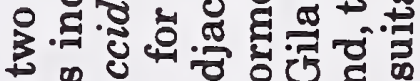

फ

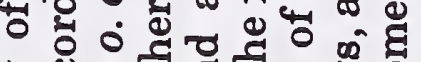

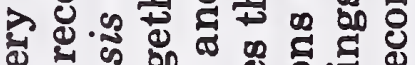

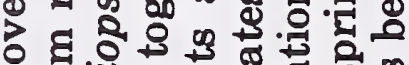

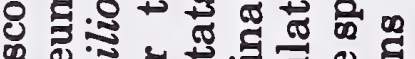

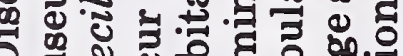
द्व
ㅎํ욜

क्ष द्व

견 공

용

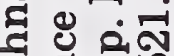

웅 $\infty$ ㄴㅇㅇ

디 ํํㄹ $\infty$

记

实

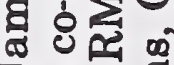

o

ช્屯

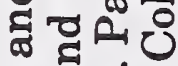

๑ึ क्ष

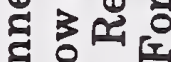

承完

$\therefore$.

령 융

동

拧䒘。

요

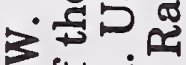

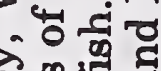

จे 品 进

붕

记宁红

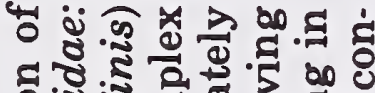

온

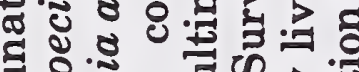

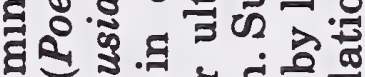

ॠ

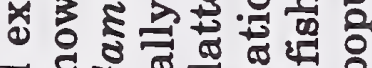

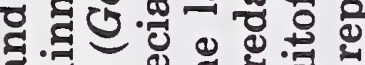

๙ 'కี

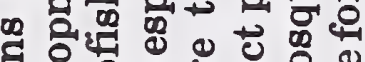

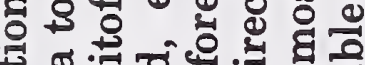

क

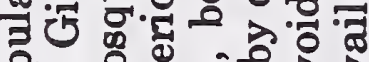

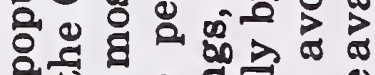

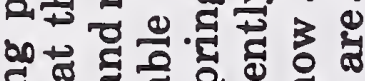

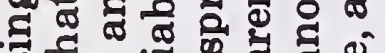

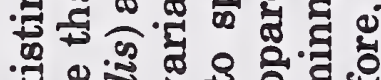

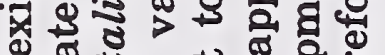

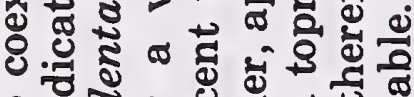

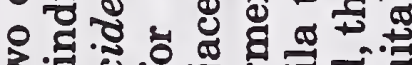

క

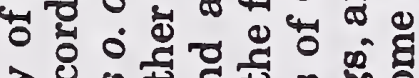

겅.

ॠ \&

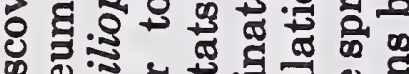

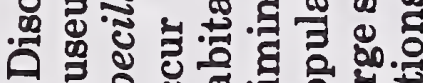
दू ฉ

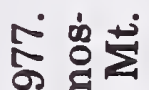

2 믹

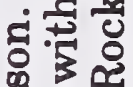

\& 8

핑 $\infty$

[.

क 융

व

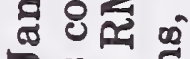

$\rightarrow$ 里

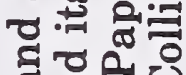

के

है कू

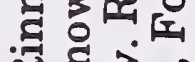

羊

之嵒饵

द्व

잉.

क्ष

ज्ञ

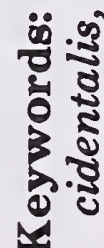

द्वे के

$5 \stackrel{0}{=}<$

千5只

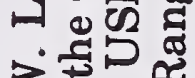

声?

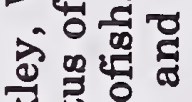

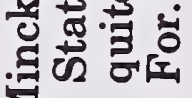

山ั่

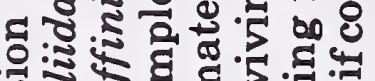

氙

ปั.

कृ

ช

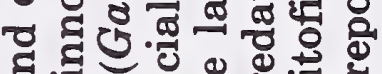

ส

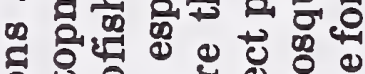

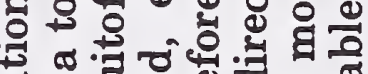

๘

응 \&

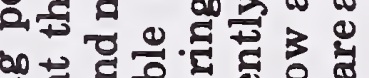

कo

. 공

.

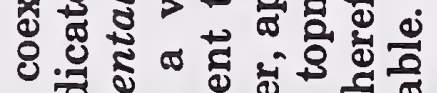

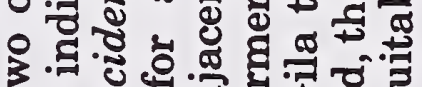

3원

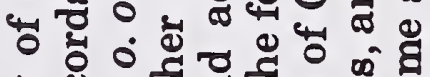

ใ.

ए

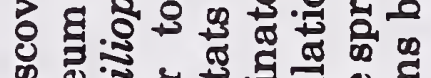

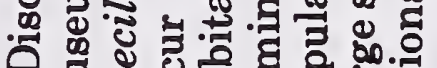

范 


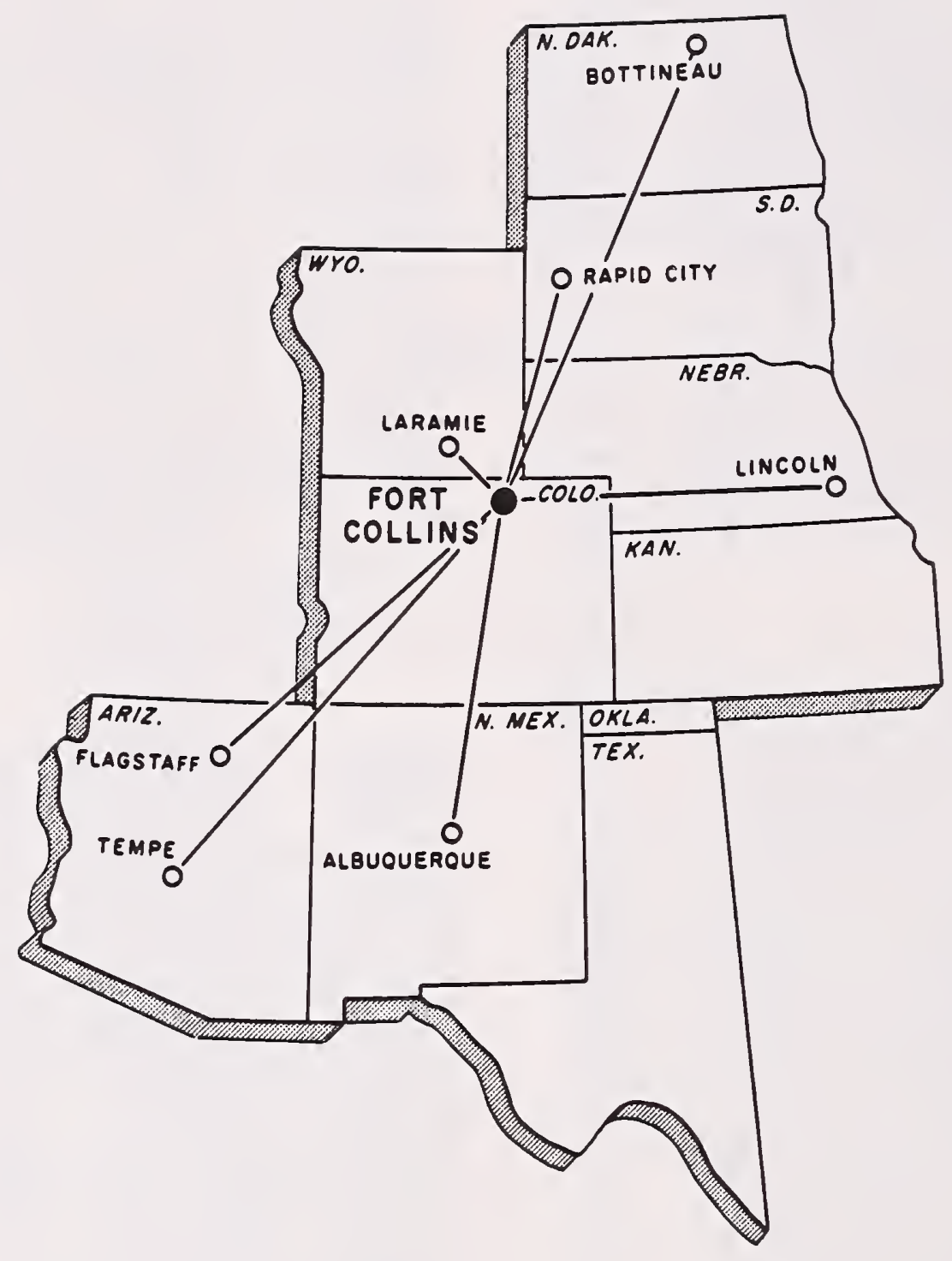

